\title{
Landscape Salinisation and Management: An Australian Perspective
}

\author{
D. Hoey ${ }^{1 *}$, M. Ahmed ${ }^{2}$, M. Littleboy ${ }^{3}$ \\ ${ }^{1}$ Department of Land and Water Conservation, PO Box 2185, Dangar, NSW, 2309 Australia \\ ${ }^{2}$ Department of Soil and Water Sciences, Sultan Qaboos University, \\ Al-Khod 123, PO Box 34, Sultanate of Oman \\ ${ }^{3}$ Department of Land and Water Conservation, PO Box 189, \\ Queanbeyan, NSW, 2620 Australia
}

\author{
تملح الأراضي وإدارتعا : وجهة نظر أسترالية \\ ديفد هوي ومشتاق احمد ومارك ليتلبوي
}

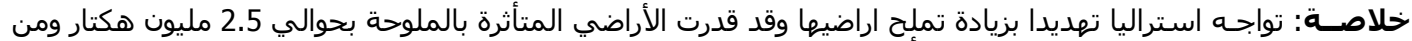

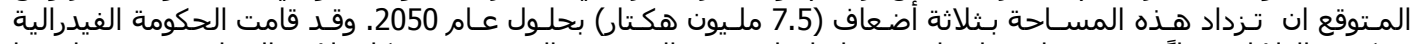

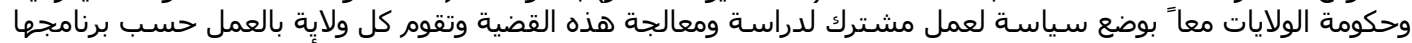

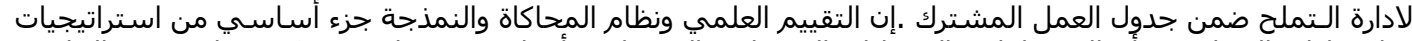

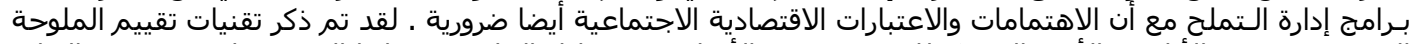

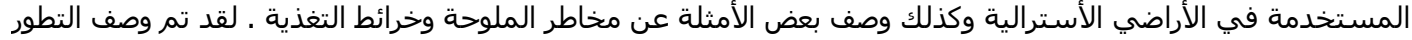

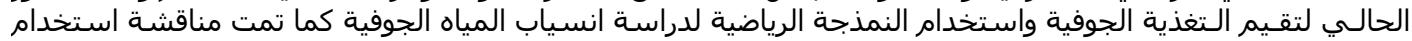

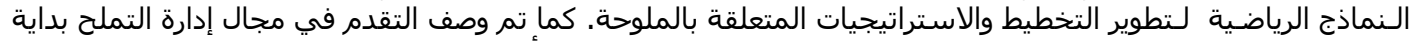

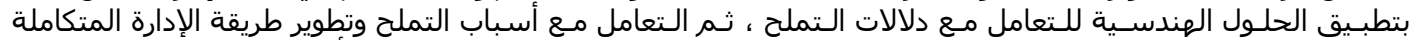

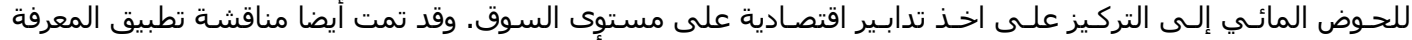

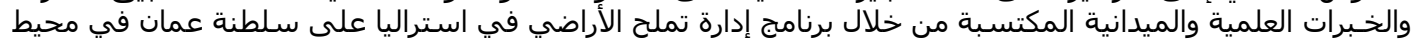

مشكلة الملوحة .
\end{abstract}

\begin{abstract}
Australian landscapes are facing an increasing salinisation threat. It is estimated that 2.5 million hectares are affected by land salinisation, and this area is expected to triple by 2050 . Federal and State governments have jointly developed a policy framework to address this issue, with each state refining their own salinity management strategies within this framework. Scientific assessment and modelling underpin these salinity management strategies, though socio-economic considerations are also important. Landscape salinity assessment techniques used in the Australian context are outlined, and examples of salinity hazard and recharge mapping at the landscape scale described. Current developments in both recharge assessment, and groundwater flow modelling in Australia are described, and the use of these models in underpinning state salinity strategic planning discussed. The salinity management 'toolkit' is discussed. The progression from initially applying engineering solutions to deal with the symptoms of salinisation; to dealing with the causes of salinisation; to developing an integrated catchment management approach; to including a stronger emphasis on market-based economic measures; and the importance of over-arching Catchment Blueprints, is described in detail.The application of knowledge and experience gained through the management of Australian land salinisation to other countries is discussed in the context of the salinity problem in the Sultanate of Oman.
\end{abstract}

Keywords: Salinisation, recharge, Australia, Integrated Catchment Management, MDBC, LWMP, FLOWTUBE, hydrological modeling, evaporation basin, desalination, Batinah, salinity strategy.

A ustralia has critical salinity and water quality problems demanding urgent attention. It is estimated that 2.5 million hectares are affected by land salinisation (Agriculture, Fisheries and Forestry -
Australia. 2002) and this area is expected to triple by 2050. This applies to all states of the Commonwealth. In Western Australia 1.8 million hectares are affected at present, and this could double within 20 years (and

*Corresponding author. 
double again before equilibrium is reached), and over half the State's surface water is already saline, brackish or of marginal quality. In South Australia, all agricultural district show some degree of dryland salinity, and at least $20 \%$ of surface water resources are above desirable salinity limits for human consumption. In Victoria, there are extensive impacts in western and central regions. In New South Wales and the ACT, as much as 7.5 million hectares could be affected in the future as groundwater rises. Even in relatively less intense areas such as Queensland severe salting affects 10,000 hectares, and in Tasmania, about 18,000 hectares (two percent of cleared agricultural land) is affected by salinity (CSIRO, 2002).

One third of Australian rivers are in extremely poor condition, partly attributable to increasing salinisation. Salinity also affects urban areas, with infrastructure (mainly buildings and roads) being severely damaged in a number of urban centres. Salinisation costs are significant, and this is expected to increase considerably in the future. While some actions have been developed across the country in response to local problems, it has been widely recognised that a co-ordinated approach to dealing with salinity is required. Accordingly, a National Action Plan for Salinity and Water Quality has been developed by the Australian Federal and State governments to address this issue. Natural resource management is a state responsibility in Australia, and each state has also developed its own salinity management strategies within this framework.

This paper will draw on the large amount of work that has been done to date in dealing with salinisation across Australia. Scientific assessment and modelling approaches will be briefly outlined, and approaches to salinity management will be described. The Murray Region Land and Water Management Plans provide an example of how a range of salinity control measures can be integrated through community action. The Hunter saline water remediation project demonstrates technology working within a policy framework that encourages to innovation.

\section{Salinity Assessment and Modelling}

Salinity mapping techniques can be divided into direct measurement of salinity outbreaks; indirect measurement; modelled (current) outbreaks; modelling of future areas at risk generated by salinity hazard assessment; and use of process models to predict future outbreaks (Please et al., 2002).

Direct salinity assessment, based on aerial photograph or satellite imagery interpretation and soil landscape mapping in the field, is the basis for most salinity assessment. While field assessment is considered most reliable (depending on the soil surveyors skills), it is time consuming, and there is only limited coverage of soil landscape maps across the country.

Indirect assessment using a range of geophysical techniques, such as radiometrics, electromagnetic induction and magnetics, can cover larger areas more quickly, but still require calibration. The signal from electromagnetic induction, for example, is a function of salinity, moisture content, soil mineralogy (Williams and Hoey, 1987) at a depth which depends on induction coil orientation. Gamma ray spectrometry measures the natural radiation from potassium, thorium and uranium in the upper $30 \mathrm{~cm}$ of the soil surface (Wilford et al., 2001) is used for regolith mapping. Again, large areas can be covered relatively cheaply, but ground truthing is required for calibration and verification (George et al., 1998).

Terrain-based models and their derivatives, such as Fuzzy Landscape Analysis using GIS (FLAG) (Summerell et al., 2001) use topographical information to predict where water will accumulate across the landscape (areas of 'wetness' and 'dryness'). This has been used in NSW to predict salt discharge areas. It can be quite effective in undulating country, but has limited value in flat terrain.

Determining areas at risk from salinisation ('salt hazard maps') are being used increasingly in planning at the catchment scale. Before the widespread use of Geographical Information Systems (GIS), Shaw et al. (1986) listed criteria indicating 'intake areas' for land susceptible to salting in Queensland. These indicators were based on vegetation types, geomorphology, geology, soil, and landholder information. This approach has been further developed as information technology has improved. For example, salinity 'indicators' (such as groundwater salinity) have been used to predict relative salinity hazard for the Northern Territory (Ticknell, 1994) and GIS and expert systems have been applied to predict recharge and discharge areas in a small catchment in South Australia (Kirkby and Kurzel, 1993).

Geology, soils, rainfall, vegetation, groundwater and landform information were used at 1:2,500,000 scale, with a 'weights of evidence' approach to determining salinity hazard across NSW (Bradd and Gates, 1996). This was based on comparing attributes such as geology and slope (the 'predictor' variables) with a 'response' map (the dryland salinity occurrence map). Weights were then calculated, by statistical bestfit, for each selected attribute. Each weighted attribute was then overlain on the GIS, to predict broad-scale salinity hazard assessment across the state.

A similar approach has been used in southeast Queensland, where 13 natural resource information 
layers were combined using an additive, weighted model to assess salinity hazard for $100 \mathrm{~m}$ grid cells (Searle and Baillie, 1998). The separate data layers were individually weighted based on knowledge of salinity processes, then combined using ARC/Info, and validated against community-derived 'Saltwatch' data.

Humphries (2000) used a lumped parameter model to assess salinity hazard for each sub-catchment within the Bogan-Castlereagh catchment (NSW) in effect producing 37 irregularly shaped cells (subcatchments), with a single output for each cell.

This approach is being developed to produce recharge maps of New South Wales by linking existing biophysical simulation modelling with statewide data sets of soils, climate, land use and topography. The data used to compile these maps will be dependent on simulation modelling. However, there has been little quantitative validation in the NSW environment, though detailed recharge validation is now in progress at four sites across NSW.

However, a review of 36 models used in Australia for catchment modelling (Marston et al., 2002) concluded that there was little standardisation of model development. Similar conclusions led the MurrayDarling Basin Commission to produce a 'best practice' guideline for groundwater flow modelling (Middlemis et al., 2001).

A review of models used in Land and Water Management Plans (LWMP) (Milner and Woolley, 1999) noted problems in integration of surface water and groundwater (and different aquifer systems), extent of available data, and relevance of timesteps used. However, models still provide a valuable means of assessing a range of management scenarios, and there is a current emphasis on integrating a range of models to examine not only the environmental effects of hydrologic change, but also socio-economic issues.

Economic models have been developed, and linked into hydrologic process models to attempt to integrate salinity management measures. For example, APSIM was used to provide estimates of recharge and runoff. FLOWTUBE used this as input to calculate hydrological and salinity implications, and SMAC, an economic model, was used to fine-tune land-use and farm income estimates (Evans, 1998).

Catchment scale hydrological modelling is essential to give spatial expression to optimisation results, including areas for implementing recommended land use changes.

\section{Engineering Solutions}

Engineering solutions focus on reclamation of saline or poorly drained areas. Horizontal drainage techniques include: large scale landforming; shallow open drains (on poorly drained flat heavy clays); deep open drains on more permeable soils; shallow mole drains (with or without perforated plastic liners); tile drainage (to depths of 2 metres); and deep 'Agpipe' drainage (up to 3 metres depth).

Vertical drainage configurations include: single wells ('tubewells', and 'production wells'); multiple single wells as part of a well field; spearpoints (multiple wells connected by a common header line); relief wells (which rely on artesian or sub-artesian pressure to 'bleed' the aquifer); and airlift pumping (particularly useful for low yield aquifers and highly aggressive saline water).

Engineering solutions generally produce saline effluent, which needs to be managed. Approaches have included: controlled (and uncontrolled) discharges to rivers or wetlands (which will often have environmental and economic consequences); using receiving waters to dilute discharges to acceptable limits; use of innovations such as Serial Biological Concentration (to irrigate progressively salt tolerant crops and trees); and detention and evaporation basins. Evaporation basins themselves may require a range of engineering solutions to control seepage.

Saline effluent is often considered a pollutant or waste. However, changing the paradigm to 'saline resource' opens up a number of opportunities to recover some of the costs in dealing with 'reject brines' (Ahmed et al., 2000). OPUS, the 'Options for Productive Use of Salinity' database (NDSP, 2001) provides a number of contact points for use of saline effluent in agriculture, forestry, fauna and algae production minerals and energy production. In NSW, this has been applied by Department of State and Regional Development to facilitate business opportunities (Department of State and Regional Development, 2002). The involvement of this department highlights the importance of integrating engineering and socio-economic considerations.

Engineering solutions can also be used in a preventative manner. Examples include seepage control along irrigation supply channels, by channel lining or using techniques such as bentonite grout curtains. There is also considerable interest in piping irrigation water supplies to reduce seepage. Engineering options such as desalination of both water supplies, and drainage water is also being seriously re-examined, due to improvements in technology and the increasing value of water.

A review of over 200 examples of engineering approaches to dealing with dryland salinity (Sinclair Knight Mertz, 2001) noted recurring problems of effluent disposal, poor economics and funding difficulties, technical difficulties, and 'negative perceptions of the engineering option'. However, the 
'social issues' are also important. Successful implementation of schemes depends on getting the support of all stakeholders (particularly local landholders adjacent to disposal areas). It is precisely the potential lack of support by a range of beneficiaries that led to a broadening of the engineering approach, to also include non-engineering solutions.

\section{Non-Engineering Solutions}

Some of these issues associated with engineering solutions (notably cost, ownership, and effluent disposal) have led planners to focus more on dealing with the causes, rather than the symptoms, of salinisation. The NSW Salinity Strategy (NSW Government, 2000) takes this broader view by focusing on eight key tools for salinity management. These involve setting end-of-valley salinity targets (to force an outcome-based focus on salinity control and address the drainage discharge issue), and developing marketbased solutions and 'environmental services investment'. It also includes promotion of business opportunities (such as commercial salt production), better-targeted government regulations and advice. Improving information systems (such as improving community access to government salinity assessments) is linked to the scientific knowledge program. Finally, planning systems at the catchment level aim to integrate salinity management and other natural resource issues.

In NSW, integration and direction is provided by Catchment Blueprints. These are drafted by the community, through Catchment Management Boards made up of natural resources users, primary producers, conservation representatives, local government, indigenous representatives and state government agencies. Catchment Management Boards operate using a collaborative community/government partnership, using a 'consensus' approach to decisionmaking, rather than "majority voting" to make joint decision. They advise the Minister for Land and Water Conservation as to appropriate natural resource management targets for their catchment. This represents a significant change of approach, from government driven reclamation and remediation, to government providing a more supportive role for regional communities to lead change themselves.

The establishment of the Cooperative Research Centre for Plant Based Solutions to Dryland Salinity in 2001 has provided a focus for research into the use of vegetation for recharge management on a catchment scale, as well as looking at the social and economic impacts of changing farming systems (Walker et al., 1999 and Stirzaker et al., 2000).
Market-based measures include assigning property rights, taxes and fines (and their counterparts incentives and subsidies) (Economic and Social Commission for Asia and the Pacific, 1998) Property rights already exist for land and water, but are now also being developed for 'pollutant rights' such as salinity credits and 'green offsets'. The Hunter River Salinity Trading Scheme has developed from load-based licensing concepts and tradeable property rights to become an effective means of lowering river salinity, while still allowing some saline discharge. It is underpinned by transparency and currency of information (usually real-time due to extensive telemetry systems which is provided by government, but paid for (on a user-pay basis) by industry).

Catchment blueprints are the primary integrating mechanism for all natural resource planning for investment in a broad range of management actions in each catchment, over a ten year planning horizon. They set overarching natural resource priorities for the catchment, and provide direction and investment guidance. Components include water management plans and regional vegetation management plans.

\section{Case Study - Murray Land and Water Management Plans}

Examination of a productive agricultural area which has been affected by salinity and drainage shows how both engineering and non-engineering solutions can be combined to tackle these problems. The Murray Irrigation Districts consist of 750,000 hectares of government-sponsored irrigation (now privately operated) located north of the Murray River and centred on the town of Deniliquin. Deniliquin is approximately $300 \mathrm{~km}$ north of Melbourne, and $700 \mathrm{~km}$ west of Sydney.

The Districts cover a range of soil types, ranging from well draining sandy soils to poorly draining heavy clays. Average rainfall is $400 \mathrm{~mm} / \mathrm{yr}$, with average evaporation rate of $1500 \mathrm{~mm} / \mathrm{yr}$. The 2300 farm holdings which make up Murray Irrigation Limited generally use a total of about $1.6 \mathrm{GL} / \mathrm{yr}$ of irrigation water, mainly for pasture for livestock, and rice. Irrigation has increased the hydraulic loading on the landscape, not only in the direct application of irrigation to crops, but also through the impact of clearing native deep rooting vegetation for farm layout, and the associated irrigation infrastructure. The 3000 $\mathrm{km}$ of supply channels crossing the landscape can interfere with the limited natural drainage that exists in such a flat (1:2000 grade) area, and roads and other development all contribute to a disrupted natural drainage system. 
The geomorphic characteristics of the region compound these problems. The districts are part of a large alluvial plain and are underlain by a number of aquifer systems which strongly influence surface conditions. Within 20 years of irrigation commencing at Wakool, waterlogging and salinisation had become significant in the district. The problem was further compounded by high groundwater salinity (averaging $30 \mathrm{dS} / \mathrm{m}$ ), and the fact that the shallow aquifers are affected to some extent by high piezometric levels in the deeper formations.

Salinity and waterlogging affect landholders directly by reducing agricultural productivity. It also indirectly impacts on infrastructure (e.g. road damage repair) and on downstream communities, through additional salt and nutrient loading in natural streams. Engineering solutions were originally developed to deal with these problems, with government sponsored surface drainage and subsurface drainage works installed. To a large extent, this provided an expensive means of maintaining the agricultural status quo, as landholders continued with the same agricultural practices which contributed to causing the initial problem. It was soon realised, however, that engineering solutions had to be combined with on-farm management and landuse change, and a reassessment of institutional arrangements (e.g. water pricing structures, water transferability, etc.) to be fully effective, and encourage a strong land stewardship ethos.

This led to the development of integrated Land and Water Management Plans (LWMP) (Berriquin Land and Water Management Plan Working Group, 1995; Denimein LWMP Working Group, 1995; Cadell Land and Water Management Plan Working Group, 1995; and Wakool Land and Water Management Plan Working Group, 1995), with its strong emphasis on community involvement and a more holistic view to landscape management (Murray and Murrumbidgee Catchment Management Committees, Undated and Murray and Murrumbidgee Catchment Management Committees, 1993).

While initially based on salinity and drainage control, the plans have developed a much wider charter. The objective of the Berriquin plan is 'to manage land salinity, high watertables and waterlogging in the Berriquin irrigation district in order to ensure the social well being, agricultural productivity and environmental sustainability of the district'. The Wakool plan's aim is simply 'to make our community a better place to live by improving the management of our natural resources'. These visions of the future were developed through extensive consultation with all stakeholders.
The extent of the problem is considered and recognised by the community, with background reports commissioned. Community-based committees then oversight investigations by technical staff in both government and private agencies, following an investigation and implementation project plan they have helped develop. Technical groups periodically report to the community groups. This allows integration of each option as it is developed, usually after lengthy debate. For Berriquin, options were based on surface drainage, sub-surface drainage, on-farm works, infrastructure development and institutional arrangements, formally linked by economic, environmental and hydrologic modelling, but linked by provision of progress reports to the Berriquin Steering Committee. However, each district is different, and so each land and water management plan has developed its own distinctive characteristics. This is crucial in retaining relevance to the community - particularly important as these plans will be setting the environmental agenda for the next 30-40 years.

Over the last few years, a dramatic shift in community involvement in decision-making in natural resource management issues has occurred. In the Murray Irrigation Districts, major salinity and drainage problems, and social issues such as privatisation forced the issue, but the District Land and Water Management Plans became a major vehicle for change.

\section{Case Study - Hunter Regional Groundwater Management for Salinity Control}

The Hunter catchment is located north of Sydney. The valley is an important agricultural, mining and industrial centre for NSW. Salinity has been recognised as a significant land degradation issue: mapping within the Hunter catchment indicates that 25,000 hectares are affected by land salinisation (Thomas, 2000). A recent salinity audit (Beale et al., 2001) noted the increasing trend of groundwater levels across the catchment, and the impact this will have on future river salinity Hunter River salinity. This has important implications for both agriculture and industry in the region.

Part of the river salinity issue is addressed by the Hunter River Salinity Trading Scheme (HRSTS) (Environmental Protection Authority, 1994). This combines load based licensing concepts with tradeable pollution rights which can be accessed under certain river flow conditions. Under this scheme, approximately 11,000 tonnes of salt have been discharged each year since 1995 while still keeping Hunter River salinity below set targets. Twenty coalmines and two power stations are currently participating in the HRSTS. Proposed changes to the HRSTS will reduce the window of opportunity for 
discharges, and require greater on-site storage of saline water (or greater trading).

However, most of the salt content in the Hunter River is due to diffuse sources. One way of dealing with this is to develop regional-scale groundwater management schemes to control saline groundwater. Control sites can be optimised using groundwater models, but disposal of saline groundwater will continue to be an issue.

While controlled river disposal has been considered 'best practice' in the past, improvements in technology, changing economic and social values, and the development of a more flexible institutional framework have created new opportunities for dealing with salinity. Given that average groundwater salinity is only around $5 \mathrm{dS} / \mathrm{m}$, desalination begins to look attractive particularly where high-value uses for desalinated water produced are located close to the desalination site, and desalination is linked with a process for recovering resources from the saline concentrate. Desalination coupled with resource recovery from saline effluent has been successfully tried in urban salinity control at two sites in NSW, and this approach may also be applicable on a larger scale in the Hunter, if the desalinated water and the salts produced can be utilised locally. This is particularly so if local synergies can be further developed through regional industrial and agricultural development.

This is currently being investigated, requiring further assessment and modelling, then linking with market forces for water and salinity credit trading and for salt products. It will also require strong community consultation, a detailed benefit-cost assessment of the project, and a partnership between government, industry and researchers to encourage innovation in creating opportunities from problems.

\section{Land Salinisation in Oman and the Application of Australian Experience for its Management}

Land salinisation is a serious problem in Oman especially in the Batinah coastal plain. This is the most important agricultural study region encompassing 80,000 ha of cultivated land (Cookson and Lepiece, 2001). A Ministry of Agriculture and Fisheries study (MAF, 1993) conducted in South Batinah concluded that $50 \%$ of the cultivated land could be classified as saline (from slightly to extremely saline). The cause of soil salinity in Batinah can be directly attributed to high levels of salt in irrigation water. Groundwater is used for irrigation and without irrigation cultivation is not possible as average rainfall is less than $125 \mathrm{~mm} / \mathrm{yr}$ and potential annual evapo-transpiration is twenty times higher. Saline water intrusion in coastal aquifers supplying irrigation water has resulted in elevated levels of salinity in groundwater. Saline water intrusion is the result of the farmers abstracting groundwater at rates much higher than annual groundwater recharge.

Efforts have been made to combat soil salinity in Batinah. Individual as well as comprehensive wellplanned government efforts have been made. Government actions, reflecting the recommendations contained in the South Batinah Integrated Study (MAF, 1993) include controlling digging of new wells and rehabilitation of older wells, construction of recharge dams, reduction of cultivated land, and developing incentives for modern irrigation systems. The main effort has been to reduce water abstraction to maintain overall water balance in the aquifers supplying irrigation water so as to prevent further saline water intrusion. Government efforts have been made with a view to making farming environmentally sustainable, economically viable and socially sustainable. In the absence of any comprehensive evaluation, it is difficult to say whether government efforts have made any significant gain to combat soil salinity.

There are similarities between the salinity situation in Oman and Australia. Agricultural practices have resulted in soil salinity, salinity has caused severe hardships for farmers, and the process has been relatively rapid (very fertile land becoming saline within a span of 10-20 years). However, there are also dissimilarities. These include physical drivers (elevated groundwater level is the main reason for salinity in Australia whereas in Oman it is due to application of saline groundwater) as well as social elements. The latter include the small size of Omani farms compared to Australian farms, and large differences with regards to application of modern technology in farming, economic and educational levels of farmers. The presence of large number of non-Arabic speaking expatriate farm workers in Oman is also different to rural Australia (which tends to have fairly homogeneous social groups), and has important implications for communication and technology transfer.

The Land and Water Management Plan concept applied in Australia could be a useful model for managing soil salinity in Oman if it is adjusted to meet local requirements for socio-economic and cultural reasons. In such plans, scientific assessments and modelling, linked to socio-economic considerations, are the basis for developing salinity management strategies for long-term environmental sustainability. Partnership between government and private enterprise underpins these plans.

Lessons learned in Australia with regards to development and implementation of Land and Water Management Plans could bring large benefits to the farmers in Batinah. 'Technology transfer' and scientific 


\section{LANDSCAPE SALINISATION AND MANAGEMENT: AN AUSTRALIAN PERSPECTIVE}

exchange would be a valuable first step in this process. This is not to say that the land and water management process has all the answers by any means. The process of development and implementation of the plans in Australia was relatively long, and testament to the difficulties encountered. However, it is certainly worth investigating as to whether such an approach is indeed suitable for Oman.

\section{Conclusions}

Landscape salinisation is an increasing problem in Australia. Different salinity assessment techniques have been developed, with varying degrees of cost, accuracy and repeatability. The use of geophysical techniques such as electromagnetic induction, radiometrics and magnetics has improved coverage and cost-effectiveness, but must always be validated on the ground. Rapid developments in information technology have blurred the boundary between assessment and modelling, and assisted scenario testing for salinity management at the catchment scale.

A range of non-engineering measures now complement the more 'traditional 'engineering solutions such as surface and sub surface drainage. Policy initiatives such as the NSW Salinity Strategy, Catchment Blueprints, and close involvement of affected communities help ensure the integration of these measures. In fact, the biggest challenge is not necessarily in technology, but in the integration of all elements (including issues of socio-economic change) to ensure long-term environmental and economic sustainability. The salinity problem continues to grow in Australia, but much has been learned, and this is reflected in the increasing integration of measures used, and the strong partnerships that are being developed to address this problem.

\section{References}

Agriculture, Fisheries and Forestry - Australia. 2002. National Action Plan for Salinity and Water Quality http://www.napswq.gov.au/publications/vital resources, html [accessed 12/9/02].

Ahmed, M., A. Arakel, D. Hoey, and M. Coleman. 2000. Integrated power, water and salt generation: A discussion paper. Desalination 134 (2001):37-45

Beale, G., R. Gilmore, M. Simmons, S. Realica, and N. Nandakumar. 2001. NSW Coastal Rivers Salinity Audit: Predictions for the Hunter Valley, DLWC, Oct 2001.

Berriquin Land and Water Management Plan Working Group, 1995. Berriquin Land and Water Management Plan. Echuca December 1995

Bradd, J. and G. Gates. 1996. The progression from site investigations to GIS analysis to map dryland salinity in NSW. In: Dryland Salinity in New South Wales - A Statewide Perspective. A Report to Salt Action, TS.95.113.
Cadell Land and Water Management Plan Working Group. 1995. Cadell Land and Water Management Plan, Echuca Printers, December 1995.

Cookson, P. and A. Lepiece. 2001. Could date palms ever disappear from the Batinah? Salination of a coastal plain in the Sultanate of Oman. Water in the Arabian Peninsula: 221-235.

CSIRO. 2002. Salinity. How big is the problem? Commonwealth Scientific and Industrial Research Organisation. http://www.clw.csiro.au/issues/salinity/ [accessed 12/9/02].

Denimein LWMP Working Group. 1995. Denimein Community's Land and Water Management Plan. Echuca, December, 1995

Department of State and Regional Development. 2002. SalinityBiz. Solutions that pay. http://wwwsalinitybiz.nsw.gov.au [accessed $11 / 3 / 02]$

Economic and Social Commission for Asia and the Pacific. 1998. Guidelines and manual on the protection and rehabilitation of contaminated rivers. Water Resources Series No. 78, United Nations, New York, 1998.

Environmental Protection Authority. 1994. Using economic instruments to control salinity in the Hunter River. Environmental Economic Series, EPA 94/21, Sydney.

Evans, R. 1998. Improving dryland salinity management through integrated catchment scale modelling. In: Proceedings of 1998 Dryland Forum, Murray-Darling Basin Commission. P.A. Jones (ed.), October 1998, Toowoomba, pp. 19-22.

George, R.J., R. Beasley, I. Gordon, D. Heislers, R. Speed, R. Brodie, C. McConnell, and P. Woodgate. 1998. Evaluation of airborne geophysics for catchment management. Final report to Agriculture, Fisheries and Forestry - Australia and National Dryland Salinity Program, for the National Airborne Geophysics Project, Dec 1998.

Humphries, E.J. 2000. Salinity risk assessment of the Central West Catchment (Macquarie, Castlereagh and Bogan catchments. Central West Catchment Management Committee, Orange, NSW, Australia.

Kirkby, S.D. and F. Kurzel. 1993. Managing dryland salinisation with an integrated GIS/ES system. LIM and GIS Conference Proceedings. Sydney, 1993.

MAF. 1993. South Batinah Integrated Study. Directorate General of Agricultural Research, Ministry of Agriculture and Fisheries, Oman.

Marston, F., R. Argent, R. Vertessy, S. Cuddy, and J. Rahman. 2002. The Status of Catchment Modelling in Australia. Cooperative Research Centre for Catchment Hydrology Technical Report 02/4.

Middlemis, H., N. Merrick, and J. Ross. 2001. Groundwater Flow Modelling Guideline. Report to Murray_Darling Basin Commission by Aquaterra Consulting, Perth.

Milner, H. and D. Woolley. 1999. Review of Land and Water Management Plan Salt Impact assessment- Project I 10006. Draft report. Internal document.

Murray and Murrumbidgee Catchment Management Committees. Undated. Guidelines for Land and Water Management Plans. Prepared in conjunction with Department of Conservation and Land Management, Sydney, NSW, Australia.

Murray and Murrumbidgee Catchment Management Committees, 1993. Guidelines for Land and Water Management Plans in Dryland Sub-Catchments. Prepared in conjunction with Department of Conservation and Land Management, Sydney, NSW, Australia.

NDSP. 2001. OPUS (Options for the Productive Use of Salinity) database. [accessed 14/3/02] http:/www.ndsp.gov.au/10_NDSP projects/30 fact_sheets/p_3_1_opus.html. National Dryland Salinity Program, Canberra.

NSW Government. 2000. Taking on the Challenge - NSW Salinity Strategy, NSW Department of Land and Water Conservation, Sydney; and Salinity Targets Supplementary Paper (October 2000). 


\section{HOEY, AHMED, AND LITTLEBOY}

Please, P., W.R. Evans, and W.D. Watson. 2002. Dryland Salinity Mapping in central and southwest New South Wales: Collation and Documentation of Information. A report prepared for the NSW National Parks and Wildlife Service.

Searle, R. and J. Baillie. 1998. Prediction of landscape salinity hazard using a Geographic Information System. Queensland Department of Natural Resources. [Accessed 4/6/01] http://www.dnr.qld.gov.au/resourcenet/land/era/projects/sham.html

Shaw, R.J., K.K. Hughes, P.J. Thorburn, and A.J. Dowling. 1986. Principles of landscape, soil and water salinity - processes and management options, Part A. In: Landscape, Soil and Water Salinity. Proceedings of the Brisbane Regional Salinity Workshop, Brisbane, May, 1987. Queensland Department of Primary Industries conference and workshop series, QC 87003.

Sinclair Knight Mertz. 2001. Assessment of the Efficacy of Engineering Options for Dryland Salinity Management Research Report Final - December 2001. A report to the Land and Water Resources Research and Development Corporation and National Dryland Salinity Program. Canberra. Accessible on http://www.ndsp.gov.au

Stirzaker, R., T. Lefroy, B. Keating, and J. Williams. 2000. A Revolution in Land Use: Emerging Land Use Systems for Managing Dryland Salinity, CSIRO Land and Water, Canberra, ACT.
Summerell, G., G.B. Beale, M.I. Miller, and T.I. Dowling. 2001. Fuzzy Landscape Analysis GIS (FLAG) modelling in the MurrayDarling System and Hunter Regions of NSW. Final report. NSW Department of Land and Water Conservation, Wagga.

Ticknell, S.J. 1994. Dryland salinity hazard map of the Northern Territory. Power and Water Authority. Report 54/94D

Thomas, D. 2000. Dryland salinity in the Hunter Valley. Department of Land and Water Conservation, Newcastle.

Wakool Land and Water Management Plan Working Group. 1995. Wakool Land and Water Management Plan. Echuca, December 1995.

Walker, G., M. Gilfedder, and J. Williams. 1999. Effectiveness of Current Farming Systems in the Control of Dryland Salinity CSIRO Land and Water, Canberra, ACT.

Wilford, J.R., D.L. Dent, T. Dowling, and R. Braaten. 2001. Rapid mapping of soils and salt stores using airborne radiometrics and digital elevation models. AGSO Research Newsletter, Number 34, p33-39, May 2001.

Williams, B.G. and D. Hoey. 1987. The use of electromagnetic induction to detect the spatial variability of the salt and clay contents of soils. Australian Journal of Soil Research 1987, 25, 21-27.

Received August 2002

Accepted November 2002. 